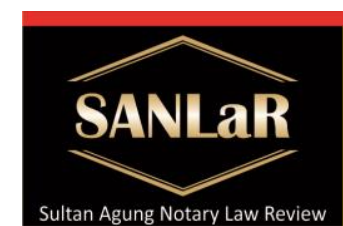

Volume 3 No. 1, March 2021
Sultan Aqung

Notary Law Review
ISSN 2686-4428

published by Faculty of Law Semarang

Legality of Notary Deals...(Ponimin)

\title{
Legality of Notary Deals Concerning Land Selling Not At Actual
}

\section{Price}

\section{Ponimin *)}

*) Student Master of Notary Law, Faculty of Law, Universitas Islam Sultan Agung Semarang, Indonesia, E-mail: mr.ponimin88@gmail.com

Abstract. Notary as PPAT is a public official who is given the authority to make authentic deeds regarding certain legal actions regarding land rights or property rights over apartment units. The formulation of the research problem is: How as a result of the notarial deed regarding the sale and purchase of land that did not match the actual price in Kendari City? This research method uses a sociological juridical approach with research specifications using descriptive research specifications. Meanwhile, the method of collecting research data is through field studies and literature studies. The data obtained were analyzed qualitatively. Qualitative analysis is carried out by describing and describing the data and facts resulting from a field study with an interpretation, evaluation, and general knowledge. The conclusions of this study are: As a result, the notary deed regarding the sale and purchase of land does not match the actual price in Kendari City has an impact on the Notary because it is not suitable Article 17 letter i Act No. 30 of 2004 concerning the Position of Notary Public. Where the action in question can affect the honor and dignity of the position of a Notary who can be subject to sanctions in accordance with Article 85 of Act No. 30 of 2004. The legal consequence is that there is a violation of Article 16 paragraph (1) of Act No. 30 of 2004 concerning the Position of Notary which may cause administrative sanctions in accordance with Article 85 of Act No. 30 of 2004 which include: a. verbal warning, $b$. written warning, c. temporary dismissal, $d$. honorific dismissal; or, e. dishonorable discharge.

Keywords: Legality; Deed; Sale and Purchase; Land; Price.

\section{Introduction}

Notary as PPAT is a public official who is given the authority to make authentic deeds regarding certain legal actions regarding land rights or property rights over apartment units. As stated in Article 2 of Government Regulation no. 37 of 1998 (PP no.27 / 1998) regulates the main tasks and obligations of PPAT, namely carrying out part of land 
registration activities by making a deed as evidence of certain legal actions regarding land rights or property rights over apartment units, which will be used as the basis for registration of changes in land registration data resulting from this legal act. This is understood because a notary is a public official whose job is to carry out public office. ${ }^{1}$

The land sale and purchase mode that does not match the actual price has the potential to cause legal problems for a notary as PPAT. Deeds issued by PPAT notaries against the sale and purchase of land that do not match the actual price are vulnerable. The validity of the deed will be the subject of the legal dispute that will occur. The dispute occurred because the sale and purchase deed was an agreement involving the parties. On the way the parties are open to the possibility of disputing because one of the parties feels that there is an achievement that is not fulfilled. Those who feel pressured by the dispute, of course, also have the potential to reveal the land sale and purchase transactions they are carrying out are not in accordance with the actual price.

With the authority possessed by the Notary as PPAT, he must pay close attention to the process of issuing the deed. The negligence that occurs not only has a legal impact on the PPAT but the deed that it issues is threatened with legal flaws. ${ }^{2}$ This must be understood because it does not rule out the possibility that there will be clients who

\footnotetext{
${ }^{1}$ Frans Hendra Winata. (2005). Persepsi Masyarat Terhadap Profesi Hukum di Indonesia. Jakarta: Renvoi Vol. December. p. 12

${ }^{2}$ Rudy Iskandar Ichlas and Akhmad Khisni, 2019, Legal Analysis on Status as A Co-Defendant Notary in Dispute of Gather Treasure (Case Study in The Court of Ungaran District No: 105 / Pdt.G / 2016 / PN.Unr) , Jurnal Akta, Volume 6 Issue 2, p. 291. Notary deed prescribed by law as legal certainty so legally quality is unquestionable. Another case, if the letter outside the provisions of the legislation it is necessary legitimacy of the authorities to be authentic
} 
want to register their land with a land sale and purchase mode that does not match the actual price.

On the other hand, the developed Kendari City has land that continues to experience price increases. This condition has an impact on income in the taxation sector. The higher the land transaction value that occurs, the tax value that will go to the state treasury will also increase. Likewise, the accumulation of land sale and purchase transactions, of course, has an impact on the income to the government treasury in the form of taxes on land.

The phenomenon of increasing land prices in Kendari City can be seen with the planned NJOP increase. As reported by Antara news agency, in early 2020 , a number of commercial areas in Kendari experienced an increase in their NJOP:

"The increase in the Sales Value of Tax Objects (NJOP) for Land and Building Tax (PBB) in Kendari City, Southeast Sulawesi Province (Sultra) will be carried out objectively, namely in the business or commercial area and will be imposed on land parcels directly facing the main road." ${ }^{13}$

As it is known that the provisions of Article 46 of Kendari City Regional Regulation Number 17 of 2013 concerning Regional Taxes (Perda No. 17/2013) state:

"The rates for Rural and Urban Land and Building Tax are determined as follows:

a. Total Tax Object Value (NJOP) is below or equal to IDR $500,000,000$, - determined at $0.1 \%$ (zero point one percent);

b. The total value of the tax object above IDR 500,000,001 $2,000,000,000$ - is determined at $0.2 \%$ (zero point two percent);

c. Total Tax Object Value IDR 2,000,000,000, - and above is determined at $0.25 \%$ (zero point twenty five percent). "

\footnotetext{
3 https: // sultra.antaranews.com/berita/ 321056/ kenaikan- njop- pbb- kendari- dilakukan- secaraobjektif, accessed on 8 February 2020
} 
It was found out later that land sellers must pay income tax and land buyers must also pay BPHTB, with the following conditions: Seller Tax $(\mathrm{PPh})=$ Selling Price $\times 2.5 \%$, Buyer Tax $($ BPHTB $)=\{$ Selling Price - Taxable Value $\} \times 5 \%$, the Buyer and the Seller then also pay for the making of a Sale and Purchase Deed (AJB) at the Notary as PPAT which will generally be borne together or if both parties agree to be borne by one of the parties whose value is a maximum of $1 \%$ of the land transaction price.

The high value of land that is the object of sale and purchase has an impact on the PPh, PPN and BPHTB that will be paid. To avoid such high costs, sellers and buyers agree to report the sale and purchase of land that does not match the actual price. Such fraudulent practices are not surprising to those who seek to profit through bogus transactions. This phenomenon causes the sale and purchase of land not according to the actual price. In fact, it does not preclude the possibility that land sale and purchase transactions submitted to public officials such as notaries do not match the actual price.

\section{Research methods}

This research method uses a sociological juridical approach with research specifications using descriptive research specifications. Meanwhile, the data collection method in this research is carried out by field studies and literature studies. The data obtained were then analyzed qualitatively. Qualitative analysis is carried out by describing and describing the data and facts resulting from a field study with an interpretation, evaluation, and general knowledge. 


\section{Results and Discussion}

\subsection{Legal Consequences of Notary Deed Regarding Land Purchase and Purchase Incompatible Prices Actually in Kendari City}

The practice of buying and selling land that does not match the real price before the Kendari City Notary is a legal event. It is understood that in a legal event there are rights and obligations legally. The content of the said rights and obligations is accommodated in the norms that accompany the legal events. In a legal event where there are rights and obligations in it automatically when there is a deviation from rights and obligations it will cause legal consequences. In relation to this research, it becomes interesting to analyze further the legal consequencesnotarial deed regarding land sale and purchase does not match the actual price in Kendari City.

As stated by Juli Yanto, a perpetratorThe sale and purchase of land does not match the actual price in Kendari City, a notary known to him provides input on the sale and purchase of land which is manipulative in the land sale and purchase transaction carried out.

"Prior to the execution of the transaction, the land owner and I as the seller had made a PPJB (Sale and Purchase Agreement) by the PPAT in their capacity as a Notary". ${ }^{4}$

Based on the facts conveyed by the informant Juli Yanto, the legal consequences can be reviewed from Act No. 30 of 2004 concerning the Position of Notary Public, as part

\footnotetext{
${ }^{4}$ July Yanto, Op. Cit Thursday, May 14, 2020
} 
of the national legal system. ${ }^{5}$. The action of the notary is not in accordance with Article 17 letter i of Act No. 30 of 2004, which states that:

"Notaries are prohibited from doing other work that is against religious norms, decency, or propriety which may affect the honor and dignity of the notary's office."

Of course, the reduction in transaction value based on the notary's suggestion is against the norm of propriety. It is fitting for the Notary / PPAT to advise against reducing the value of the transaction so that there is no state loss. The decrease in transaction value will of course reduce the value of BPHTB duties that will be deposited into the regional treasury. It is said that the state loss is due to the state revenue that goes to the regional treasury not in accordance with the true value due to transactions reported by taxpayers that have been manipulated. This proves that the Notary / PPAT has committed acts contrary to the norms of decency which can affect the honor and dignity of the notary's office, and may be subject to sanctions in accordance with Article 85 of Act No. 30 Of 2004 which states:

"Violation of the provisions referred to in Article 17 may be subject to sanctions in the form of:
a. verbal warning;
b. written warning;
c. temporary suspension;
d. honorific dismissal; or
e. dishonorable discharge."

\footnotetext{
${ }^{5}$ Imam Syaukani and A.Ahsin Thohari. (2007). Dasar-Dasar Politik Hukum. Jakarta: Rajagrafindo Persada. p 65. The national legal system is a legal system (covering material and formal; principal and sectoral) built on the basis of the state ideology Pancasila and the 1945 Constitution, and is applicable throughout Indonesia.
} 
Referring to Act No. 28 of 2009 concerning Regional Taxes and Regional Retributions, the Notary / PPAT who served Juli Yanto's research informants was clearly an act that violated Article 91 paragraph (1) of Act No. 28 of 2009, as stated as following:

"The Official for Making Land Deeds / Notaries can only sign the deed of transferring Rights to Land and / or Buildings after the Taxpayer submits proof of tax payment."

Observing the provisions of Article 91 paragraph (1) of Act No. 28 of 2009, regarding the practice of buying and selling land that does not match the actual price carried out by informants, of course it produces evidence of tax payment which is not true, which is actually known by the Notary concerned because both PPJB and AJB are the same Notary / PPAT products.

The violation of Article 91 paragraph (1) above will have legal consequences for the said Land Deed / Notary Official. The provisions contained in Act No. 28 Of 2009 provide the threat of administrative sanctions. As stipulated in Article 93 paragraph (1) of Act No. 28 of 2009, it is stated that:

"Land Deed Making Officials / Notaries and heads of offices in charge of state auction services, who violate the provisions referred to in Article 91 paragraph (1) and paragraph (2) shall be subject to administrative sanctions in the form of a fine of IDR 7,500,000.00 (seven million five hundred thousand rupiah) for each violation. "

Considering Article 93 paragraph (1) of Act No. 28 of 2009 states that the administrative sanctions imposed are applicable for each violation, according to what has been described above proves that the Notary / PPAT concerned has accumulated two violations, namely contributing to the issuance of proof of tax payment not real 
and issuing AJB that does not match the actual price. Departing from these facts, the Notary / PPAT should be subject to administrative sanctions in accordance with Article 93 paragraph (1) of Act No. 28 of 2009 in an accumulative manner, namely $2 \times$ IDR 7,500,000.00 (seven million five hundred thousand rupiah = IDR 15,000. 000.00 (fifteen million rupiah).

As a positive law that has been established by the state ${ }^{6}$ then a profession as regulated in Act No. 30 of 2004 concerning the Position of Notary Public, the Notary concerned is also bound by Article 16 paragraph (1) letter $d$ which requires that:

"In carrying out his position, a Notary is obliged to provide services in accordance with the provisions of this Law, unless there is a reason to refuse it."

If there is a violation of Article 91 paragraph (1) of Act No. 28 of 2009 by a Notary / PPAT as disclosed above, the Notary has neglected his obligation to provide services in accordance with the provisions of the Law as instructed in Article 16 paragraph (1) of the Act No. 30 Of 2004. Violation of Article 16 paragraph (1) of Act No. 30 Of 2004 has legal consequences for the Notary Public, which in accordance with Article 85 of Act No. 30 Of 2004 states that:

"Violation of the provisions referred to in Article 7, Article 16 paragraph (1) letter $a$, Article 16 paragraph (1). Letter b, Article 16 paragraph (1) letter $c$, Article 16 paragraph (1) letter d, Article 16 paragraph (1) letter e, Article 16 paragraph (1) letter f, Article 16 paragraph (1) letter g, Article 16 paragraph (1) letter $h$, Article 16 paragraph (1) letter i, Article 16 paragraph (1) letter $j$, Article 16 paragraph (1) letter $k$, Article 17, Article 20, Article 27, Article 32, Article 37, Article 54, Article 58, Article 59, and / or Article 63, may be subject to sanctions in the form of:

\footnotetext{
${ }^{6}$ A'an Efendi, Freddy Poernomo and IG.NG Indra S. Ranuh. (2016). Teori Hukum. Jakarta: Sunar Grafika. p. 61
} 

a. verbal warning;
b. written warning;
c. temporary suspension;
d. honorific dismissal; or
e. dishonorable discharge. "

It is different when the transaction is not actually a personal initiative of the applicant for the sale and purchase of land deed who is not involved or even does not know the bad intentions of the deed applicant. The notary may assume that the applicant for deed must be considered as a party with good intentions.

One of the informants of this research, namely Rima Anggrinyani, SH, M.Kn., Notary / PPAT whose working area is in Kendari City, admits that the practice of buying and selling land does not match the actual price before a notary in Kendari. According to him, the issued deed remains as authentic deed in general where its validity is not in doubt as long as the Notary does not know the actions of the applicant for the deed regarding the price which does not match the price.

"If the party who is buying and selling agrees to a price that is not in accordance with the notary, that is fine. The notary did not know the agreement. "7

What was stated by informant Rima Anggrinyani, SH, M.Kn., Notary / PPAT, it is true. Although it is not in accordance with the provisions as long as the parties or parties who feel aggrieved by the issuance of the deed and cannot be proven otherwise, the deed is still valid as an authentic evidence. However, in the opinion of Rima Anggrinyani, SH, M.Kn., It is impossible to say that the Notary who published the deed

\footnotetext{
${ }^{7}$ Interview with Rima Anggriya, Saturday, July 182020 in Kendari
} 
did not match the actual price without his knowledge. This is due to the fact that the PPJB deed and the sale and purchase certificate (AJB) were issued by the same Noyaris / PPAT. Even if what is conveyed by Rima Anggrinyani, SH, M.Kn., Notary / PPAT, it is true, the Notary who issued the price which is not actually acting inaccurate or not careful in processing the deed to be issued. As the procedure, ${ }^{8}$

As a PPAT, the notary concerned has violated the oath of office in accordance with Article 11 of the Regulation of the State Minister for Agrarian Affairs / Head of the National Land Agency Number 4 of 1999 concerning Provisions for Implementing Government Regulation Number 37 of 1998 concerning the Position Regulations for Land Deed Making Officials."

"That I will carry out my position honestly, orderly, carefully and with full awareness, responsibility and impartiality".

As a result of the legal violation of Article 11 of the Regulation of the State Minister for Agrarian Affairs / Head of the National Land Agency Number 4 of 1999 concerning Provisions for Implementing Government Regulation Number 37 of 1998, the above mentioned sanctions may be subject to sanctions as regulated in Article 6, namely:

(1). The sanctions imposed on IPPAT members who violate the Code of Ethics can be in the form of:

a. Carefull;

b. warning;

c. schorsing (temporary dismissal) from membership of the IPPAT association;

d. onzetting(dismissal) from membership of the IPPAT association; and

e. dishonorable discharge from membership of the IPPAT association.

\footnotetext{
${ }^{8}$ Santia Dewi and R.M. Fauwas Diradja. (2011). Panduan Teori dan Praktik Notaris. Yogyakarta: Pustaka Yustisia. p. 37
} 
(2). The imposition of sanctions as referred to in paragraph (1) against members of the IPPAT association who violates the Code of Ethics is adjusted to the frequency and quality of violations committed by members of the IPPAT association.

(3). The imposition of sanctions as referred to in paragraph (1) and paragraph (2) will result in the imposition of sanctions which will be given later by the PPAT supervisor".

Application Article 11 Regulation of the State Minister for Agrarian Affairs / Head of the National Land Agency Number 4 of 1999 above is law enforcement as an affirmation of legal certainty. Theoretically, the Regulation of the State Minister for Agrarian Affairs / Head of the National Land Agency Number 4 of 1999 as positive law should be applied without any doubts. Because it is understood that by implementing positive law accompanied by doubts it will lead to multiple interpretations of the applied law. Law that has multiple interpretations is a separate problem from the aspect of legal certainty. Without legal certainty, the potential for conflict is very open. Departing from this fact, an absolute legal event is accompanied by legal certainty.

\section{Closing}

\subsection{Conclusion}

The legal consequence of the notary deed regarding the sale and purchase of land does not match the actual price in Kendari City has an impact on the Notary because it is not suitable Article 17 letter i Act No. 30 of 2004 concerning the Position of Notary Public. Where the action in question can affect the honor and dignity of the position of a Notary who can be subject to sanctions in accordance with Article 85 of Act No. 30 of 2004. The legal consequence is that there is a violation of Article 16 paragraph (1) of Act No. 30 of 2004 concerning the Position of Notary which can lead to administrative 
sanctions in accordance with Article 85 of Act No. 30 of 2004 which include: a. verbal warning; b. written warning; c. temporary suspension; d. honorific dismissal; or e. dishonorable discharge."

\subsection{Suggestion}

In order to anticipate the behavior of manipulating taxes on BPHTB duties, a legal reconstruction is needed by making the fourth amendment to the Kendari City Regional Regulation Number 2 of 2011 concerning Regional Taxes by adding norms regarding high fines in order to trap perpetrators of buying and selling land at prices that are not true before a notary.

\section{References}

Journal:

Rudy Iskandar Ichlas and Akhmad Khisni, 2019, Legal Analysis on Status as A CoDefendant Notary in Dispute of Gather Treasure (Case Study in The Court of Ungaran District No: 105 / Pdt.G / 2016 / PN.Unr) , Jurnal Akta, Volume 6 Issue 2

Books:

[1] A'an Efendi, Freddy Poernomo and IG.NG Indra S. Ranuh. (2016). Teori Hukum. Jakarta: Sunar Grafika

[2] Frans Hendra Winata. (2005). Persepsi Masyarat Terhadap Profesi Hukum di Indonesia. Jakarta: Renvoi Vol. December

[3] Imam Syaukani and A.Ahsin Thohari. (2007). Dasar-Dasar Politik Hukum. Jakarta: Rajagrafindo Persada

[4] Santia Dewi and R.M. Fauwas Diradja. (2011). Panduan Teori dan Praktik Notaris. Yogyakarta: Pustaka Yustisia

Internet:

https: // sultra.antaranews.com/berita/ 321056/ kenaikan- njop- pbb- kendaridilakukan- secara-objektif, accessed on 8 February 2020 
Interview:

Interview with Rima Anggriya, Saturday, July 182020 in Kendari 